\title{
ANALYSIS ON SOLAR PANEL PERFORMANCE AND PV-INVERTER CONFIGURATION FOR TROPICAL REGION
}

\author{
E. A. Setiawan ${ }^{1 *}$, A. Setiawan ${ }^{1}$, D. Siregar ${ }^{1}$
}

\begin{abstract}
In this paper, proper inverter topology for tropical region will be determined with temperature effect as a considered factor. PV characteristics on certain temperature are obtained through mathematical equations in MATLAB-Simulink and it will be represented by PV I-V and P-V characteristic curves. Based on the modeling, some PV parameters such as temperature coefficients of short circuit current $\left(\mathrm{I}_{\mathrm{SC}}\right)$, open circuit voltage $\left(\mathrm{V}_{\mathrm{OC}}\right)$, maximum output power $\left(\mathrm{P}_{\mathrm{MAX}}\right)$, and maximum power voltage $\left(\mathrm{V}_{\mathrm{MP}}\right)$ can be determined as high as $0.56 \% / \mathrm{oC}$, $-0.31 \% / \mathrm{oC}-0.4 \% / \mathrm{oC}$, and $0.43 \% / \mathrm{oC}$ respectively. As the result, for tropical region, the central inverter is the most proper inverter topology to supply $5 \mathrm{~kW}_{\mathrm{AC}} \mathrm{PV}$ system, string inverter in the 2nd place, and AC module with utility rates of $97.34 \%, 96.32 \%$, and $88.1 \%$ based on direct measurement on PV panel's temperature respectively. From NOCT approach, the utility rates are around $92.96 \%$ for central inverter, $91.98 \%$ for string inverter and 91.8 $\%$ for AC module.
\end{abstract}

Keywords: Photovoltaic, PV-Inverter Configuration, PV Modeling, Solar Panel Characteristics, Temperature, Tropics

\section{INTRODUCTION}

Photovoltaic (PV) has been widely utilized to produce electricity from solar energy because of its simplicity, low maintenance, and ecofriendly reason. Both of PV's I-V (current-voltage) and P-V (power-voltage) are shown by figure 1. PV V-I and P-V curve represent its power conversion characteristic at certain temperature and irradiation. I-V curve shows the possible combinations of current and voltage output of a photovoltaic (PV) device. On the other hand, P-V curve is obtained from voltage and current multiplication. VMP and IMP represent PV's maximum power voltage and maximum power current respectively [1].

PV electrical characteristic such as maximum output power (PMP), open circuit voltage (Voc), short circuit current (ISC), maximum power voltage (VMP), and maximum power current (IMP) are strongly affected by temperature fluctuation. Figure 2 shows temperature fluctuation effect on PV I-V curve. Blue curve and red curve represents PV I-V curve before and after temperature rise respectively. Even though PV short circuit current (ISC) slightly increase, open circuit voltage (VOC) are significantly decrease due to temperature rise. As the result, temperature rise lead to reduction on PV maximum output power.

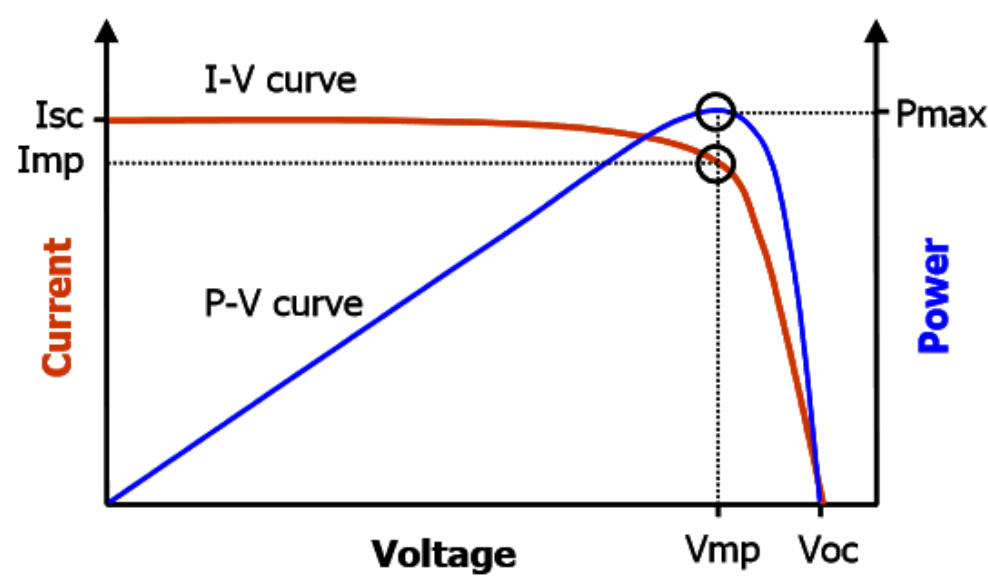

Figure 1. I-V and P-V curves of a photovoltaic device [1]

This paper was recommended for publication in revised form by Regional Editor Hafiz Muhammad Ali

1 Electrical Engineering Department, Faculty of Engineering, TREC Universitas Indonesia, Depok 16424, Indonesia

${ }^{*}$ E-mail address: ekoas@eng.ui.ac.id

Manuscript Received 22 January 2016, Accepted 9 June 2016 
The standard test condition (STC) of PV specifies a PV module in temperature of $25^{\circ} \mathrm{C}$, an irradiance of $1000 \mathrm{~W} / \mathrm{m}^{2}$ with an AM 1.5 spectrum and zero wind speed [3]. On the other hand, ambient temperature in tropical region can reach up to $40{ }^{\circ} \mathrm{C}$ [4]. Therefore, the standard test condition (STC) of PV cannot fully represent the performance of $\mathrm{PV}$ in tropical region.

As a part of PV system, solar inverter is used to convert PV DC power to AC power. The basic inverter topologies for PV are shown by figure 3. Figure 3.a shows central solar inverter topology where PV are arranged series and parallel forming an array and connected to single inverter. Figure 3.b represent string inverter topology. It consist of several PV module which are arranged in series forming a string. Every string is connected to one string inverter. Figure 3.c shows AC-module concept. It consist a PV module which is connected to low-power solar inverter [5]. These inverters play a key role in the energy efficiency and reliability since they operate the PV array at the Maximum Power Point (MPP) [5]. Therefore, PV array maximum power point is one factor to be considered to choose proper inverter topology.

However, due to its effect on PV electrical parameters, temperature rise on PV can also affect solar inverter choosing. PV electrical parameters are important to determine PV solar inverter topology because different inverter topology has different specification of power $\left(\mathrm{P}_{\mathrm{MP}}\right)$, open circuit voltage $\left(\mathrm{V}_{\mathrm{OC}}\right)$, short circuit current $\left(\mathrm{I}_{\mathrm{SC}}\right)$, maximum power voltage $\left(\mathrm{V}_{\mathrm{MP}}\right)$, and maximum power current $\left(\mathrm{I}_{\mathrm{MP}}\right)$. Hence, temperature fluctuation on PV also affect solar inverter topology choosing.

This paper discuss about PV solar inverter choosing on tropical region that has high temperature characteristic. The proper inverter topology can be determined by analyzing the effect of temperature and irradiation on the PV panel. The effect of temperature and irradiation will be represented by PV I-V and P-V

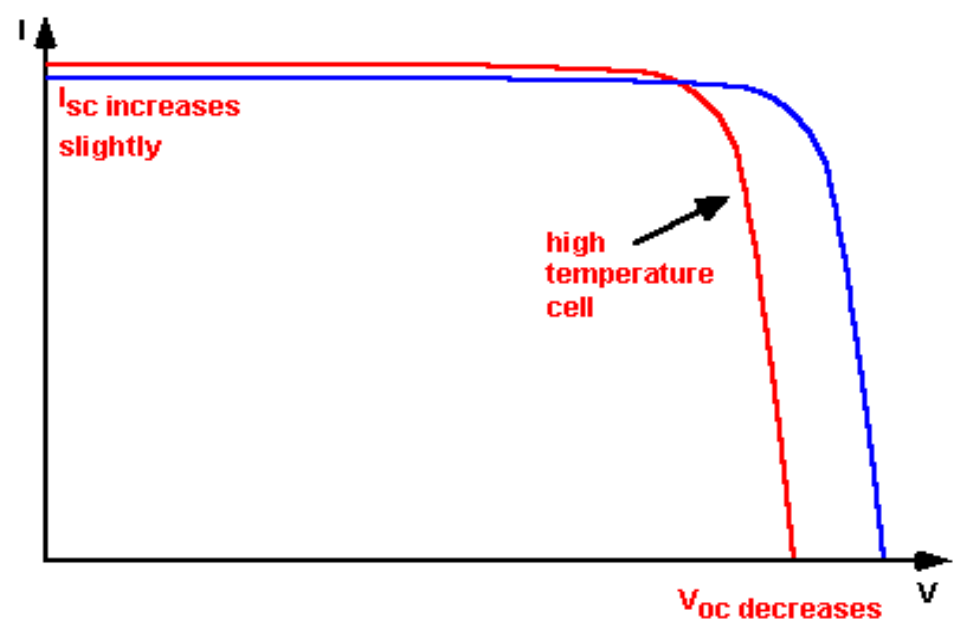

Figure 2. The effect of temperature rise on the PV I-V characteristics curve [2]

(a)

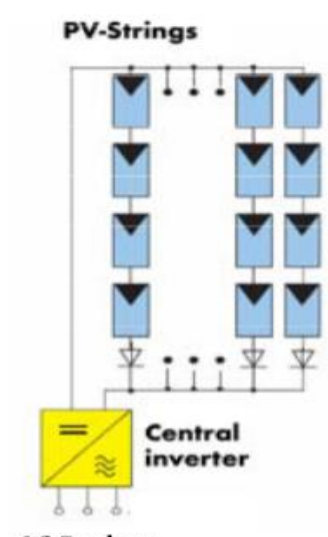

(b)

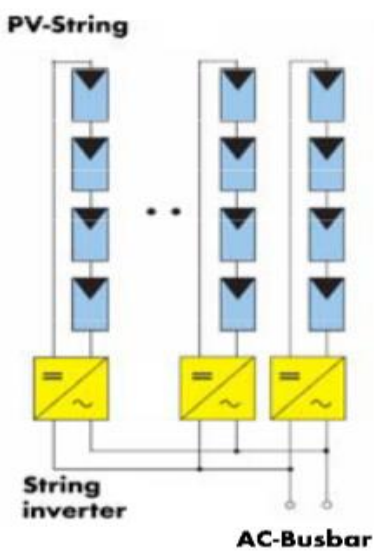

(c)

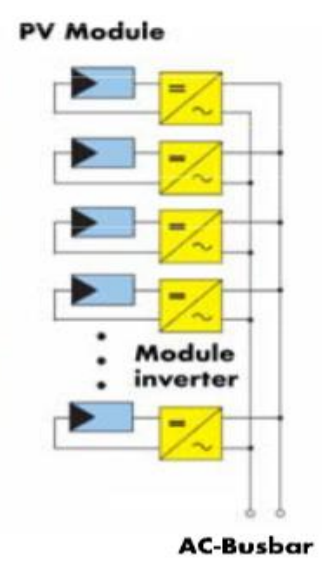

Figure 3. Solar Inverter Topology [5] 
curves. PV characteristics on certain temperature would be analyzed using Solar panel modeling through MATLAB Simulink based on mathematical equations that form PV characteristic curve.

\section{PV MODELING}

The modeled PV module is represented as diagrams blocks those are formed by mathematical current's equations of photovoltaic such as reverse saturation current (Irs), saturation current (Io), and photocurrent (Iph). The current equation are shown by equation 1, 2, and 3 respectively [6].

$$
\begin{aligned}
& \frac{I s c}{\left[\exp \left(\frac{(q)(V o c)}{(N s)(K)(n)(T)}\right)\right]} \\
& I o=\operatorname{Irs}\left(\frac{T}{\operatorname{Tref}}\right)^{3} \exp \left[\frac{(q)(E g)}{(n)(k)}\left(\frac{1}{\operatorname{Tref}}-\frac{1}{T}\right)\right] \\
& I p h=[I s c+K(T-298)] \frac{G}{1000 W m^{-2}}
\end{aligned}
$$

PV's output current is obtained by using both photocurrent (Iph) and saturation current (Io), which is represented by equation 4 [5].

$$
I p v=(N p)(I p h)-(N p)(I o)\left[\exp \left(\frac{(q)(V p v)}{(N s)(n)(k)(T)}\right)-1\right]-\frac{(V p v)+(I p v)(R s)}{R s h}
$$

The modeled PV-A is represented by block diagram in figure 4. PV-A modeling is conducted to obtain PV characteristic curve. As input variable, input voltage $\left(\mathrm{V}_{\text {in }}\right)$, normalized radiation, and temperature are used. Input voltage is represented as ramp function which have gradient (m) of 1. In STC, output current (IPV) is equal to PV's STC short circuit current (ISC_STC) if $\mathrm{V}_{\text {in }}$ equal to $0 \mathrm{~V}$. On the other hand, (IPV) is equal to $0 \mathrm{~A}$ if $\mathrm{V}_{\text {in }}$ is equal to PV's STC open circuit voltage (VOC_STC). The block diagram also shows the modeled PV-A power and current with the value of $255.4 \mathrm{~W}$ and 8.89 A respectively. Technical specification of the modeled PV-A are shown by table 1 .

\section{MODELING VERIFICATION}

Verification is needed in order to ensure that modeled PV-A has same characteristic as the actual one. Figure 4 and figure 5 shows modeled PV-A I-V and P-V characteristic curve respectively as the result of MATLABSimulink simulation. From the simulation, value of short circuit current (ISC), open circuit voltage (VOC) and maximum output power (PMP) can be obtained. The parameters which are obtained from the simulation are compared to the actual parameters from PV datasheet. Comparison of the parameters are shown in table 2.

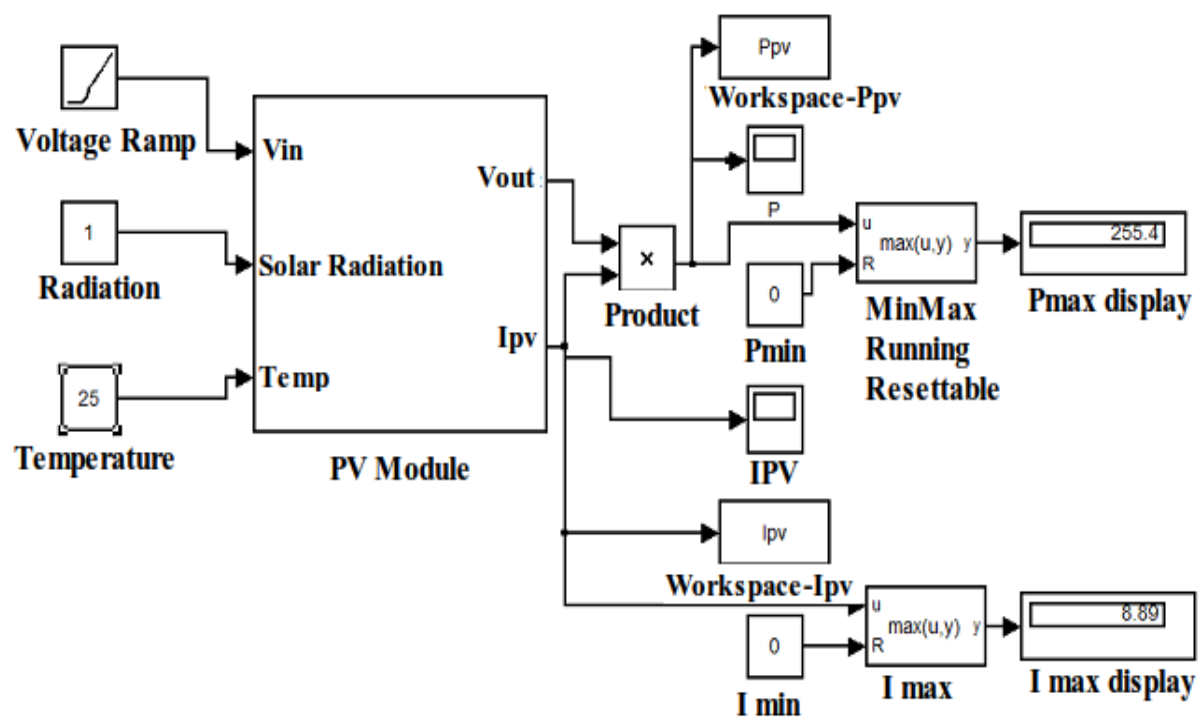

Figure 4. Modeled PV-A block diagram from MATLAB-Simulink 
Table 1. PV-A Specification

\begin{tabular}{|c|c|}
\hline Type & Monocrystalline \\
\hline Maximum output power $\left(\mathrm{P}_{\max }\right)$ & $255 \mathrm{~W}_{\mathrm{p}}$ \\
\hline PTC (PV USA Test) & $230.5 \mathrm{~W}_{\mathrm{p}}$ \\
\hline Short-circuit Current $\left(\mathrm{I}_{\mathrm{SC}}\right)$ & $8.89 \mathrm{~A}$ \\
\hline Maximum Point Current $\left(\mathrm{I}_{\mathrm{MP}}\right)$ & $8.18 \mathrm{~A}$ \\
\hline Open-circuit Current $\left(\mathrm{V}_{\mathrm{OC}}\right)$ & $37.8 \mathrm{~V}$ \\
\hline Maximum Point Voltage $\left(\mathrm{V}_{\mathrm{MP}}\right)$ & $31.2 \mathrm{~V}$ \\
\hline Air Mass $(\mathrm{AM})$ & 1.5 unit \\
\hline Ideality Factor $(\mathrm{n})$ & 1.5 \\
\hline No. of cells & 60 \\
\hline NOCT & $45{ }^{\circ} \mathrm{C}$ \\
\hline Temperature coefficient of $\mathrm{I}_{\mathrm{SC}}$ & $0.056 \% \mathrm{per}^{\circ} \mathrm{C}$ \\
\hline PV's efficiency & $16.7 \%$ \\
\hline Fill Factor $(\mathrm{FF})$ & 0.758 \\
\hline PV's total surface's area & $1.46 \mathrm{~m}^{2}$ \\
\hline
\end{tabular}

Table 2. Electrical Parameters Comparison of Actual and Modeled PV-A

\begin{tabular}{|c|c|c|c|}
\hline & PV-A & Modeled PV-A & Error (\%) \\
\hline $\mathrm{I}_{\mathrm{SC}}$ & $8.89 \mathrm{~A}$ & $8.89 \mathrm{~A}$ & 0 \\
\hline $\mathrm{V}_{\mathrm{OC}}$ & $37.8 \mathrm{~V}$ & $37.78 \mathrm{~V}$ & 0.053 \\
\hline $\mathrm{P}_{\mathrm{MP}}$ & $255 \mathrm{~W}$ & $255.4 \mathrm{~W}$ & 0.16 \\
\hline
\end{tabular}

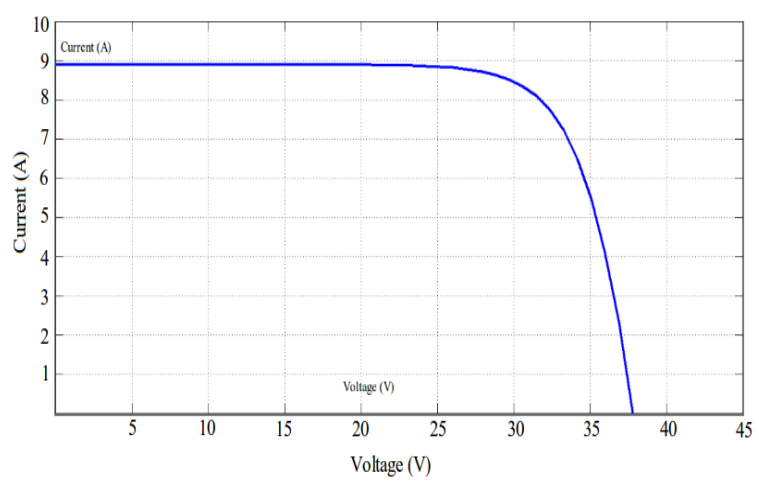

Figure 5. Modeled PV-A Current-Voltage (I-V) characteristic curve under Standard Test Condition (STC)

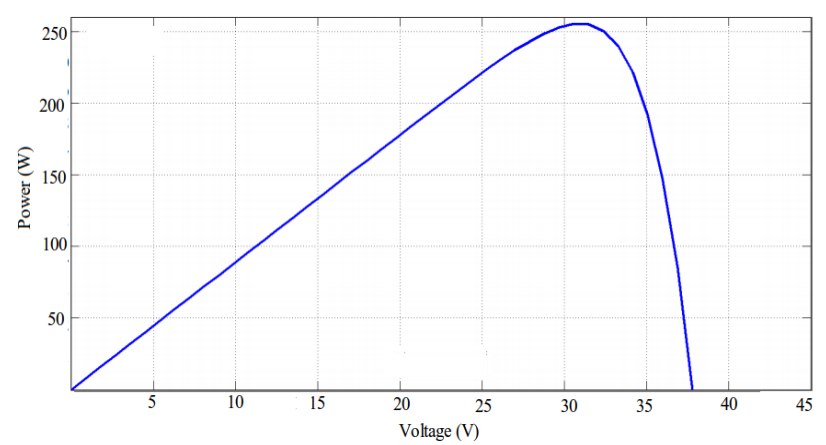

Figure 6. Modeled PV-A Power-Voltage (P-V) characteristic curve under Standard Test Condition (STC)

Table 2 shows that all parameters has percentage of error less than $0.2 \%$. It means that PV modeling has been done properly. 


\section{PV CELL TEMPERATURE ON TROPICAL REGION}

Ambient temperature strongly affect PV's cell temperature and as the result, it affect PV performance. Equation 5 shows simple approach to determine cells temperature based on NOCT (Normal Operating Cell Temperature) approach [7].

$T_{-}$cell $=T_{-}$ambient $+\frac{N O C T-20}{80} x S$

Jakarta is chosen as representation for tropical region. Monthly temperature data of Jakarta are shown by the table 3 .

Based on equation 5, maximum and minimum PV cell temperature in Jakarta can be obtained. The maximum and minimum PV cell temperature are $58.14^{\circ} \mathrm{C}$ and $58.25^{\circ} \mathrm{C}$ respectively.

As a comparison, actual temperature measurement is also conducted on PV cell. The measurement result is shown by table 4. Based on real measurement Maximum and Minimum cell temperature are $38.9{ }^{\circ} \mathrm{C}$ and 67.9 ${ }^{\circ} \mathrm{C}$ respectively.

The different results between NOCT approach and actual measurement can occur because actually, relation between ambient temperature and cell temperature is a complex thing. Both of results are used for further calculation and analysis.

Table 3. Jakarta ambient temperature data

\begin{tabular}{|c|c|}
\hline Month & Temperature $\left({ }^{\circ} \mathrm{C}\right)$ \\
\hline January & 26.89 \\
\hline February & 27.03 \\
\hline March & 27.35 \\
\hline April & 27.51 \\
\hline May & 27.25 \\
\hline June & 27.15 \\
\hline July & 27.52 \\
\hline August & 27.92 \\
\hline September & 28 \\
\hline October & 27.33 \\
\hline November & 26.97 \\
\hline December & 27.37 \\
\hline Average & 27.36 \\
\hline
\end{tabular}

Table 4. Result of PV cell temperature measurement

\begin{tabular}{|c|c|}
\hline $\mathrm{G}\left(\mathrm{W} / \mathrm{m}^{2}\right)$ & PV Cell Temp. $\left({ }^{\circ} \mathrm{C}\right)$ \\
\hline 293 & 38.9 \\
\hline 302 & 39.9 \\
\hline 369 & 43.1 \\
\hline 378 & 43.1 \\
\hline 511 & 46.8 \\
\hline 531 & 46.8 \\
\hline 542 & 46.8 \\
\hline 630 & 53.7 \\
\hline 649 & 53.7 \\
\hline 679 & 53.7 \\
\hline 709 & 58.7 \\
\hline 716 & 58.7 \\
\hline 722 & 58.7 \\
\hline 786 & 59.4 \\
\hline 804 & 59.4 \\
\hline 816 & 59.4 \\
\hline 866 & 67.9 \\
\hline 880 & 67.9 \\
\hline 882 & 67.9 \\
\hline
\end{tabular}




\section{INVERTER SPECIFICATION}

Calculation and analysis are conducted to obtain proper inverter topology to supply $5 \mathrm{~kW}_{\mathrm{AC}}$ load in tropical region. Central inverter, string inverter, and AC-Module are analyzed. Table 5 shows Inverter specification which are used in calculation.

\section{RESULT}

\section{PV modeling result}

\section{Temperature's effect on PV characteristic curve}

The first simulation is conducted in order to investigate temperature effect on PV performance, the simulation is conducted under constant irradiance of $1000 \mathrm{~W} / \mathrm{m}^{2}$ and varying temperature. I-V and P-V characteristic curves under temperature variation is shown by figure 7 and 8 respectively.

Table 5. The analyzed inverter specification

\begin{tabular}{|c|c|c|c|}
\hline \multirow{2}{*}{ Specification } & \multicolumn{3}{|c|}{ Inverter } \\
\cline { 2 - 4 } & $5 \mathrm{~kW}_{\mathrm{AC}}$ & $2.5 \mathrm{~kW}_{\mathrm{AC}}$ & $230 \mathrm{~W}_{\mathrm{AC}}$ \\
\hline Nominal Power (W) & 5000 & 2500 & 230 \\
\hline Input Voltage ( $\left.\mathrm{V}_{\mathrm{DC}}\right)$ & $240-600$ & $195-600$ & $24-40$ \\
\hline Input Current (A) & 30 & 20 & 10.4 \\
\hline Efficiency (\%) & 96 & 95 & 95.2 \\
\hline Euro/CEC weighted Efficiency (\%) & 95.2 & 94 & 94.1 \\
\hline
\end{tabular}

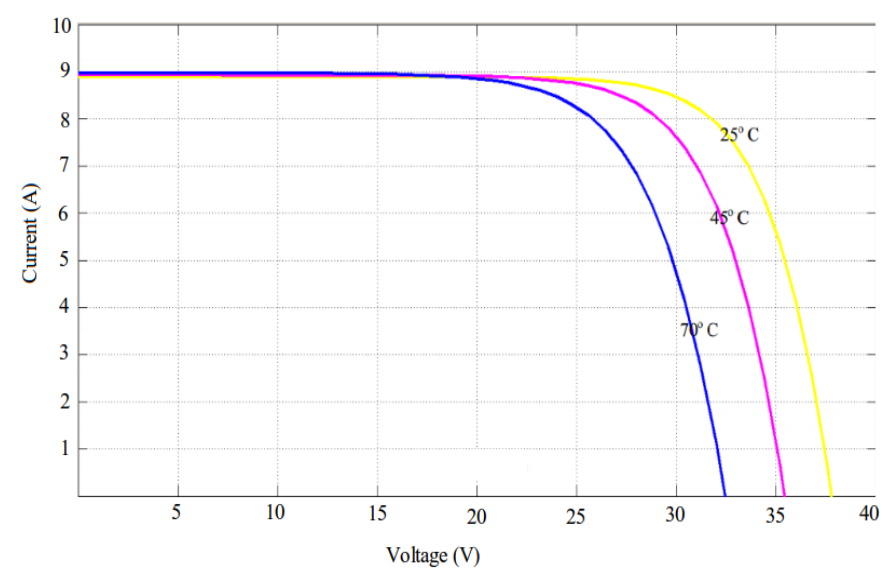

Figure 7. Modeled PV-A Current-Voltage (I-V) characteristic curve with temperature variation and constant irradiance

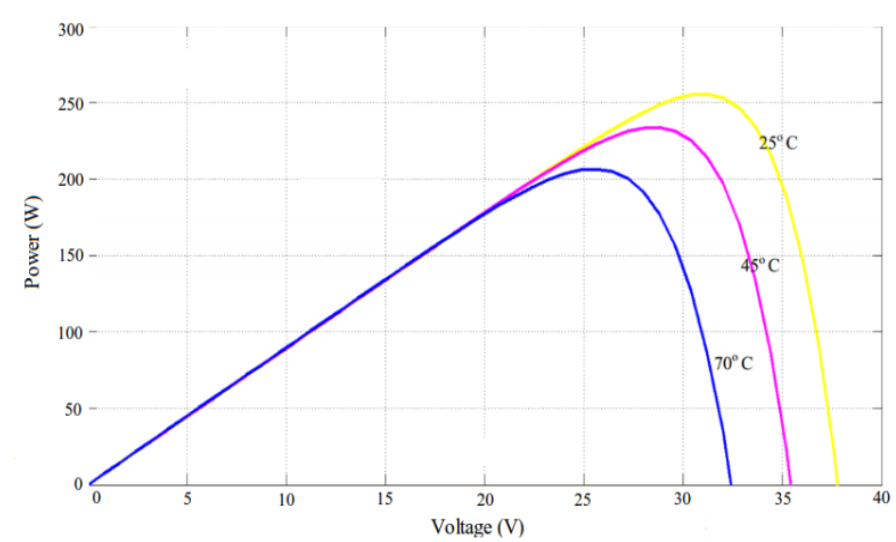

Figure 8. Modeled PV-A Power-Voltage (P-V) characteristic curve with temperature variation and constant irradiance 
Based on figure 8, temperature rise is inversely proportional to maximum power $\left(\mathrm{P}_{\mathrm{MP}}\right)$ and open circuit voltage $\left(\mathrm{V}_{\mathrm{OC}}\right)$. On the other hand, figure 7 shows that temperature rise is slightly proportional to short circuit current ( $\left.\mathrm{I}_{\mathrm{SC}}\right)$. As the temperature increases, the rate of the photon generation increases. Consequently the reverse saturation current increases rapidly and this reduces the band gap. Hence this leads to marginal changes in the current but major changes in voltage [8].

\section{Irradiation effect on PV characteristic curve}

The second simulation is conducted in order to determine the effects irradiation on PV performance. The modeled PV is simulated under varying irradiance and constant temperature of $25^{\circ} \mathrm{C}$. I-V and $\mathrm{P}-\mathrm{V}$ characteristic curves under irradiance variation is shown by figure 9 and 10 respectively.

Based on figure 10, amount of irradiation is significantly affect PV maximum power $\left(\mathrm{P}_{\mathrm{MP}}\right)$. It is because as irradiation increases, both of PV output voltage and current increase. Figure 9 shows that irradiation have great influence especially to PV output current due to irradiation effect to the number of free electrons on PV, where greater the amount of irradiation speed up the process of electrons excitation on PV.

\section{PV temperature coefficient}

From the simulation which is conducted, temperature coefficients of short circuit current (ISC), open circuit voltage $\left(\mathrm{V}_{\mathrm{OC}}\right)$, maximum output power $\left(\mathrm{P}_{\mathrm{MAX}}\right)$, and maximum power voltage $\left(\mathrm{V}_{\mathrm{MP}}\right)$ can be obtained. The coefficients can be used to calculate $\mathrm{I}_{\mathrm{SC}}, \mathrm{V}_{\mathrm{OC}}, \mathrm{P}_{\mathrm{MAX}}, \mathrm{V}_{\mathrm{MP}}$ in certain earth's surface's certain point with temperature as parameter. The temperature coefficient can be obtained through the equation 6 .

$$
\alpha=\frac{\left(X_{S T C}-X\right)}{\left(X_{S C T}\right) x(\Delta T)} \times 100 \%
$$

Modeled PV-A is simulated to operate at temperature $25^{\circ} \mathrm{C}$ to $75^{\circ} \mathrm{C}$. From the temperature variation, the temperature coefficients of short circuit current $\left(\mathrm{I}_{\mathrm{SC}}\right)$, open circuit voltage $\left(\mathrm{V}_{\mathrm{OC}}\right)$, maximum output power $\left(\mathrm{P}_{\mathrm{MAX}}\right)$, maximum point voltage $\left(\mathrm{V}_{\mathrm{MP}}\right)$ can be obtained as high as $0.056 \% /{ }^{\circ} \mathrm{C},-0.31 \% /{ }^{\circ} \mathrm{C}$ and $-0.39 \% /{ }^{\circ} \mathrm{C},-0.43$ $\% /{ }^{\circ} \mathrm{C}$ respectively.

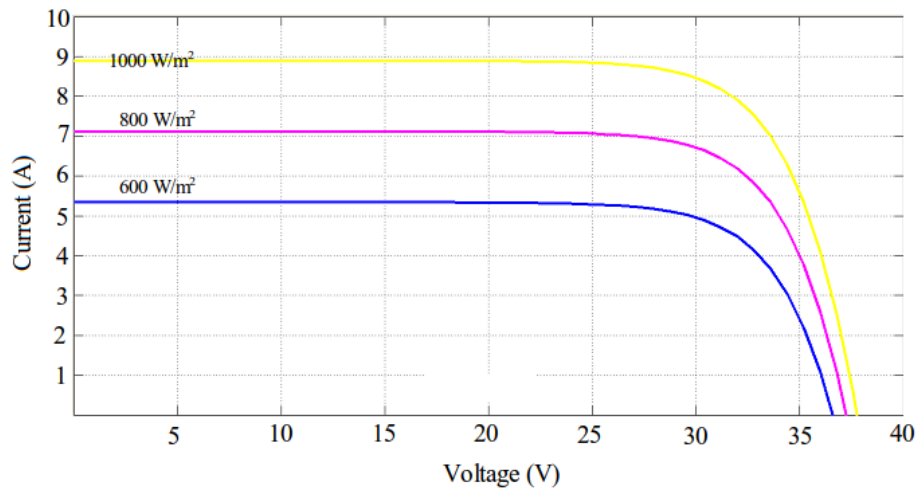

Figure 9. Modeled PV-A Current-Voltage (I-V) characteristic curve with irradiance variation and constant temperature

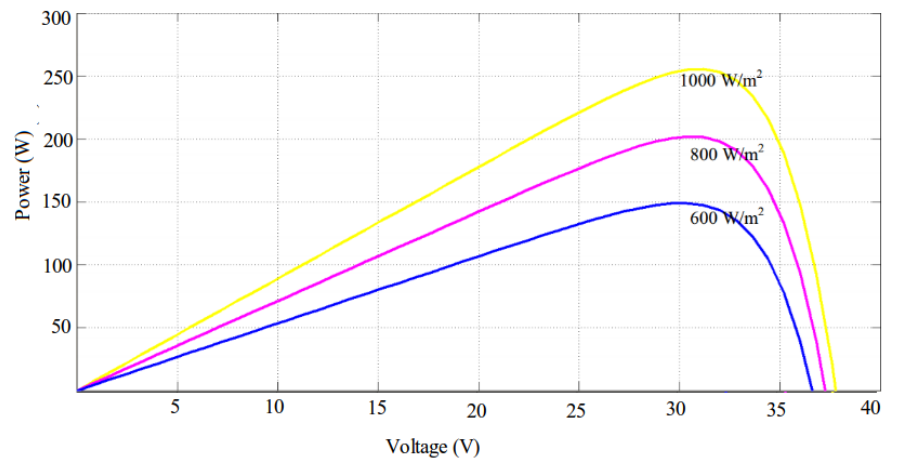

Figure 10. Modeled PV-A Power-Voltage (P-V) characteristic curve with irradiance variation and constant 


\section{PV Inverter Selection}

Calculation on $\mathrm{V}_{\mathrm{OC}}$ and $\mathrm{V}_{\mathrm{MP}}$ values based on tropical region temperature characteristic are conducted to determine numbers of $\mathrm{PV}$ which are used for each inverter topology. Value of $\mathrm{V}_{\mathrm{OC}}$ is used to determine maximum $\mathrm{PV}$ voltage in low temperature and value of $\mathrm{V}_{\mathrm{MP}}$ is used to determine minimum PV's voltage in high temperature. Therefore, PV inverter can still operate effectively even though PV cell temperature are fluctuate. The calculation is conducted based on real PV cell temperature measurement and NOCT approach.

Maximum $\mathrm{V}_{\mathrm{OC}}$ for every module is obtained by the equation 7.

$\left.V O C_{\mathrm{MAX}}=V O C_{\mathrm{STC}}+\left(\left(T_{\mathrm{MIN}}-T_{\mathrm{STC}}\right) \times V O C_{\mathrm{TEMP} . \mathrm{COEFF}}\right)\right) \times V O C_{S T C}$

Maximum number of modules connected in series (string) is obtained by equation 8 .

$$
N M O D U L E_{M A X}=\frac{V D C_{M A X}}{V O C_{M A X}}
$$

Minimum $\mathrm{V}_{\mathrm{MP}}$ for every module is obtained by the equation 9.

$\left.V M P_{\mathrm{MIN}}=V M P_{\mathrm{STC}}+\left(\left(T_{\mathrm{MIN}}-T_{\mathrm{STC}}\right) \times V M P_{\mathrm{TEMP} . C O E F F}\right)\right) \times V M P_{S T C}$

Minimum number of modules connected in series (string) is obtained by equation 10 .

$$
N M O D U L E_{M I N}=\frac{V D C_{M I N}}{V M P_{M I N}}
$$

Maximum number of string connected to Inverter is limited by output current of total PVs in a string. It is obtained by equation 11 .

$$
N_{\text {STRING }}=\frac{I_{I N V}}{I M P_{S T C}}
$$

Maximum tolerable converted power of PVs which is represented by PV's number is obtained by equation 12.

$$
\left.\mathrm{P}_{\mathrm{o}}=\left(\mathrm{P}_{\mathrm{o} \_\mathrm{STC}}+\left(\left(\mathrm{T}_{\mathrm{MAX}}-\mathrm{T}_{\mathrm{STC}}\right) \times \mathrm{P}_{\mathrm{o} \_ \text {TEMP COEFF }}\right)\right) \mathrm{x} \mathrm{P}_{\mathrm{o} \_\mathrm{STC}}\right) \mathrm{x} \eta_{\mathrm{INV}}
$$

Utility rates of inverter is shown by equation 13 .

$$
\% \frac{P o}{P_{-} I N V}=\frac{P o}{P_{-} I N V} \times 100 \%
$$

Based on the PV-A and inverters specification which are shown by table 1 and table 5, calculation on each inverter topology are conducted by using equation 7 to equation 13 . Result of calculation is shown by table 6 , table 7 , and table 8 .

The calculation result are used to choose some of PV strings and array combination on each inverter topology. Output power and utility rates of arranged PV for each inverter topology are shown by table 9 to table 12. PV inverter utility rate is the key parameter to determine the proper inverter topology. It represents compatibility between PV inverter and PV panel. Furthermore, due to temperature effect on PV maximum output power, PV inverter utility rate is also affected by temperature fluctuation.

Table 6. Parameters calculation result for central inverter topology

\begin{tabular}{|c|c|c|}
\hline & $\begin{array}{c}\text { Direct Measurement } \\
\text { Calculation }\end{array}$ & $\begin{array}{c}\text { NOCT } \\
\text { Approach }\end{array}$ \\
\hline V $_{\text {OC_MAX }}$ & $36.17 \mathrm{~V}$ & $33.91 \mathrm{~V}$ \\
\hline $\mathrm{V}_{\text {MP_MIN }}$ & $25.4 \mathrm{~V}$ & $26.6 \mathrm{~V}$ \\
\hline $\mathrm{N}_{\text {MODULE_MAX }}$ & 16 & 17 \\
\hline N $_{\text {MODULE_MIN }}$ & 10 & 10 \\
\hline N $_{\text {STRING_ }}$ & 3 & 3 \\
\hline
\end{tabular}


Table 7. Parameters calculation result for the string inverter topology

\begin{tabular}{|c|c|c|}
\hline & $\begin{array}{c}\text { Direct Measurement } \\
\text { Calculation }\end{array}$ & $\begin{array}{c}\text { NOCT } \\
\text { Approach }\end{array}$ \\
\hline $\mathrm{V}_{\text {OC_MAX }}$ & $36.15 \mathrm{~V}$ & $33.91 \mathrm{~V}$ \\
\hline $\mathrm{V}_{\text {MP_MIN }}$ & $25.4 \mathrm{~V}$ & $26.6 \mathrm{~V}$ \\
\hline $\mathrm{N}_{\text {MODULE_MAX }}$ & 16 & 17 \\
\hline $\mathrm{N}_{\text {MODULE_MIN }}$ & 8 & 8 \\
\hline $\mathrm{N}_{\text {STRING }}$ & 1 & 1 \\
\hline
\end{tabular}

Table 8. Parameters calculation result for ac-module

\begin{tabular}{|c|c|c|}
\hline & $\begin{array}{c}\text { Direct Measurement } \\
\text { Calculation }\end{array}$ & $\begin{array}{c}\text { NOCT } \\
\text { Approach }\end{array}$ \\
\hline $\mathrm{V}_{\text {OC_MAX }}$ & $36.15 \mathrm{~V}$ & $33.91 \mathrm{~V}$ \\
\hline $\mathrm{V}_{\text {MP_MIN }}$ & $25.4 \mathrm{~V}$ & $26.6 \mathrm{~V}$ \\
\hline $\mathrm{N}_{\text {MODULE_MAX }}$ & 1 & 1 \\
\hline $\mathrm{N}_{\text {MODULE_MIN }}$ & 1 & 1 \\
\hline
\end{tabular}

Table 9. PV maximum output power and inverter utility rates for central inverter topology based on direct measurement on pv panel's temperature

\begin{tabular}{|c|c|c|c|}
\hline \multicolumn{5}{|c|}{ One String } \\
\hline Configuration & $\begin{array}{c}\text { Total } \\
\text { Modules }\end{array}$ & Po (W) & Po/P INV $(\%)$ \\
\hline A & 10 & 2027.92 & 40.56 \\
\hline B & 11 & 2230.71 & 44.61 \\
\hline C & 12 & 2433.50 & 48.67 \\
\hline D & 13 & 2636.30 & 52.73 \\
\hline E & 14 & 2839.09 & 56.78 \\
\hline F & 15 & 3041.88 & 60.84 \\
\hline \multicolumn{5}{|c|}{ Two Strings } \\
\hline Configuration & Total & Po (W) & Po/P INV $(\%)$ \\
\hline G & 20 & 4055.84 & 81.12 \\
\hline H & 22 & 4461.43 & 89.23 \\
\hline I & 24 & 4867.01 & 97.34 \\
\hline J & 26 & 5272.6 & 105.45 \\
\hline K & 28 & 5678.18 & 113.56 \\
\hline L & 30 & 6083.76 & 121.67 \\
\hline \multicolumn{5}{|c|}{ Three Strings } \\
\hline Configuration & Total & Po (W) & Po/PINV $(\%)$ \\
\hline M & 30 & 6083.7696 & 121.675392 \\
\hline N & 33 & 6692.14656 & 133.8429312 \\
\hline O & 36 & 7300.52352 & 146.0104704 \\
\hline P & 39 & 7908.90048 & 158.1780096 \\
\hline R & 42 & 8517.27744 & 170.3455488 \\
\hline & 45 & 9125.6544 & 182.513088 \\
\hline
\end{tabular}

Based on table 9 and 10, there are some configuration with different PV strings and array combination for central inverter topology. Table 9 shows that based on direct measurement on PV panel's temperature, configuration I is the best configuration for central inverter with total PV-A modules of 24, it have the best utility rates i.e. $97.34 \%$ and based on NOCT approach, the best configuration for central inverter topology is configuration $\mathrm{H}$ with utility rates of $92.96 \%$.

String inverter topology uses one PV' string for each PV solar inverter PV. Table 11 and table 12 show that the optimum number of PV module for string inverter is 12 modules with utility rates of $96.32 \%$ based on direct measurement on PV panel's temperature and 11 modules with utility rates of $91.98 \%$ based on NOCT approach . In addition, two string inverter are needed to supply $5 \mathrm{~kW}_{\mathrm{AC}}$ system. Therefore, $24 \mathrm{PV}$ modules and 22 
Table 10. PV maximum output power and inverter utility rates for central inverter topology based on NOCT approach

\begin{tabular}{|c|c|c|c|}
\hline \multicolumn{4}{|c|}{ One String } \\
\hline Configuration & $\begin{array}{c}\text { Total } \\
\text { Modules }\end{array}$ & Po (W) & $\mathrm{Po} / \mathrm{P}_{\mathrm{INV}}(\%)$ \\
\hline $\mathrm{A}$ & 10 & 2112.63 & 42.25 \\
\hline $\mathrm{B}$ & 11 & 2323.89 & 46.48 \\
\hline $\mathrm{C}$ & 12 & 2535.15 & 50.70 \\
\hline $\mathrm{D}$ & 13 & 2746.41 & 54.93 \\
\hline $\mathrm{E}$ & 14 & 2957.67 & 59.15 \\
\hline $\mathrm{F}$ & 15 & 3168.94 & 63.37 \\
\hline \multicolumn{4}{|c|}{ Two Strings } \\
\hline Configuration & $\begin{array}{c}\text { Total } \\
\text { Modules }\end{array}$ & Po (W) & $\mathrm{Po} / \mathrm{P}_{\text {INV }}(\%)$ \\
\hline $\mathrm{G}$ & 20 & 4225.25 & 81.12 \\
\hline $\mathrm{H}$ & 22 & 4647.77 & 92.96 \\
\hline $\mathrm{I}$ & 24 & 5070.3 & 101.41 \\
\hline $\mathrm{J}$ & 26 & 5492.82 & 109.85 \\
\hline $\mathrm{K}$ & 28 & 5915.35 & 118.31 \\
\hline $\mathrm{L}$ & 30 & 6337.87 & 126.76 \\
\hline \multicolumn{4}{|c|}{ Three Strings } \\
\hline Configuration & $\begin{array}{c}\text { Total } \\
\text { Modules }\end{array}$ & Po (W) & $\mathrm{Po} / \mathrm{P}_{\mathrm{INV}}(\%)$ \\
\hline $\mathrm{M}$ & 30 & 6337.88 & 126.75 \\
\hline $\mathrm{N}$ & 33 & 6971.67 & 139.43 \\
\hline $\mathrm{O}$ & 36 & 7605.45 & 152.10 \\
\hline $\mathrm{P}$ & 39 & 8239.24 & 164.78 \\
\hline $\mathrm{Q}$ & 42 & 8873.02 & 177.460 \\
\hline $\mathrm{R}$ & 45 & 9506.82 & 190.14 \\
\hline
\end{tabular}

Table 11. PV maximum output power and inverter utility rates for string inverter topology based on direct measurement on PV panel's temperature

\begin{tabular}{|c|c|c|}
\hline \multicolumn{3}{|c|}{ Single String } \\
\hline Number of Modules & $\mathrm{P}_{\mathrm{o}}(\mathrm{W})$ & $\mathrm{Po}_{\mathrm{P}} \mathrm{P}_{\mathrm{INV}}(\%)$ \\
\hline 8 & 1605.44 & 64.22 \\
\hline 9 & 1806.12 & 72.24 \\
\hline 10 & 2006.8 & 80.27 \\
\hline 11 & 2207.48 & 88.3 \\
\hline 12 & 2408.16 & 96.32 \\
\hline 13 & 2608.84 & 104.35 \\
\hline 14 & 2809.52 & 112.38 \\
\hline 15 & 3010.2 & 120.41 \\
\hline
\end{tabular}

PV modules are needed for string inverter topology based on direct measurement on PV panel's temperature and NOCT approach respectively.

AC module topology use small capacity inverter which can only be utilize by a PV. Therefore, to supply $5 \mathrm{~kW}_{\text {AC }}$ system, 24 AC module are needed. Table 5 shows that the specification of small inverter is enough to compensate PV-A $255 \mathrm{~W}_{\mathrm{p}}$. By using equation 14 and equation 15, utility rates percentage of AC module topology can be obtained, i.e. $88.1 \%$ for real cell temperature measurement and $91.8 \%$ for NOCT calculation.

The maximum utility rates comparison on three different inverter topology are shown by figure 11 and figure 12. It can be concluded that with high temperature characteristic of tropical region, central inverter is the best topology to supply $5 \mathrm{~kW}_{\mathrm{AC}}$ system compared to other inverter topology because it have best utility rates based on both of direct measurement on PV panel's temperature and NOCT approach. 
Table 12. PV maximum output power and inverter utility rates for central inverter topology based on NOCT calculation

\begin{tabular}{|c|c|c|}
\hline \multicolumn{3}{|c|}{ Single String } \\
\hline Number of Modules & $\mathrm{P}_{\mathrm{o}}(\mathrm{W})$ & $\mathrm{Po}_{\mathrm{P}} \mathrm{P}_{\mathrm{INV}}(\%)$ \\
\hline 8 & 1672.5 & 66.89 \\
\hline 9 & 1881.56 & 75.26 \\
\hline 10 & 2090.62 & 83.62 \\
\hline 11 & 2299.68 & 91.98 \\
\hline 12 & 2508.74 & 100.35 \\
\hline 13 & 2717.8 & 108.7 \\
\hline 14 & 2926.86 & 117.075 \\
\hline 15 & 3135.93 & 125.46 \\
\hline
\end{tabular}

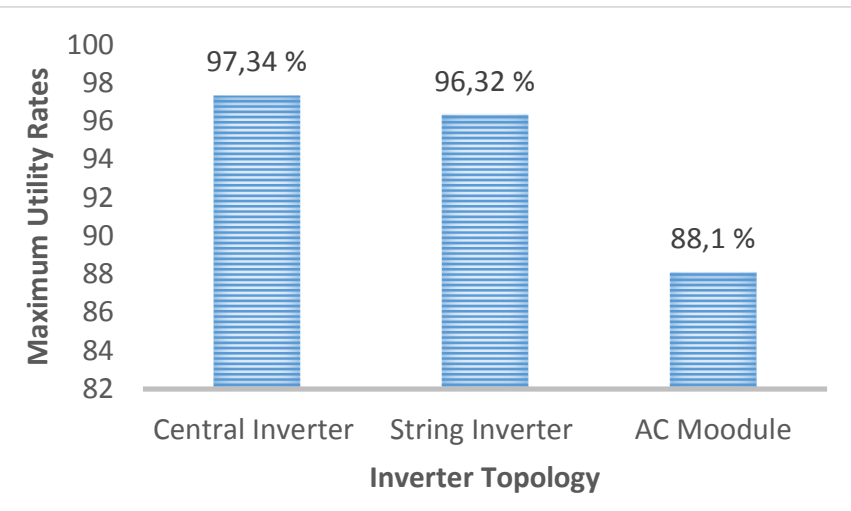

Figure 11. Comparison of inverter topology maximum utility rates based on real temperature measurement

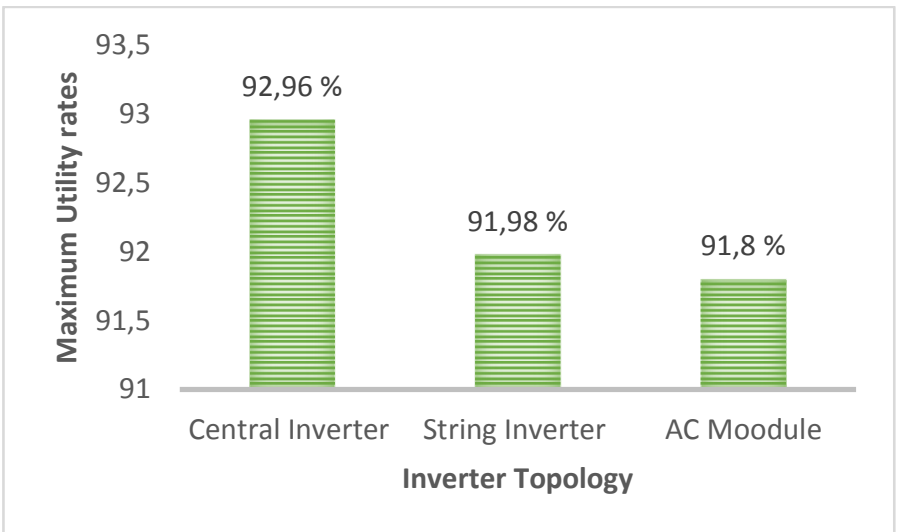

Figure 12. Comparison of inverter topology maximum utility rates based on NOCT approach

\section{CONCLUSION}

This research successfully accomplish PV-A modeling and the results are temperature coefficients of short circuit current $\left(\mathrm{I}_{\mathrm{SC}}\right)$, open circuit voltage $\left(\mathrm{V}_{\mathrm{OC}}\right)$, maximum output power $\left(\mathrm{P}_{\mathrm{MAX}}\right)$, and maximum power voltage $\left(\mathrm{V}_{\mathrm{MP}}\right)$ consecutively as high as $0.56 \% /{ }^{\circ} \mathrm{C},-0.31 \% /{ }^{\circ} \mathrm{C}-0.4 \% /{ }^{\circ} \mathrm{C}$, and $0.43 \% /{ }^{\circ} \mathrm{C}$. Central inverter is the most proper inverter topology to supply $5 \mathrm{~kW}_{\mathrm{AC}}$ system in tropical area with utility rates of $97.34 \%$ and $92.96 \%$ for real cell temperature measurement and NOCT calculation. On the other hand, string inverter topology has utility rates of $96.32 \%$ and $91.98 \%$ for real cell temperature measurement and NOCT calculation, and ACmodule topology has utility rates of $88.1 \%$ and $91.8 \%$ for real cell temperature measurement and NOCT calculation.

\section{NOMENCLATURE}

$\begin{array}{ll}\mathrm{T}_{\mathrm{ref}} & \text { Referenced temperature }(298 \mathrm{~K}) \\ \mathrm{E}_{\mathrm{g}} & \text { Semiconductor band-gap energy }(\mathrm{eV}) \\ \mathrm{N}_{\mathrm{p}} & \text { Number of cells in parallel }\end{array}$




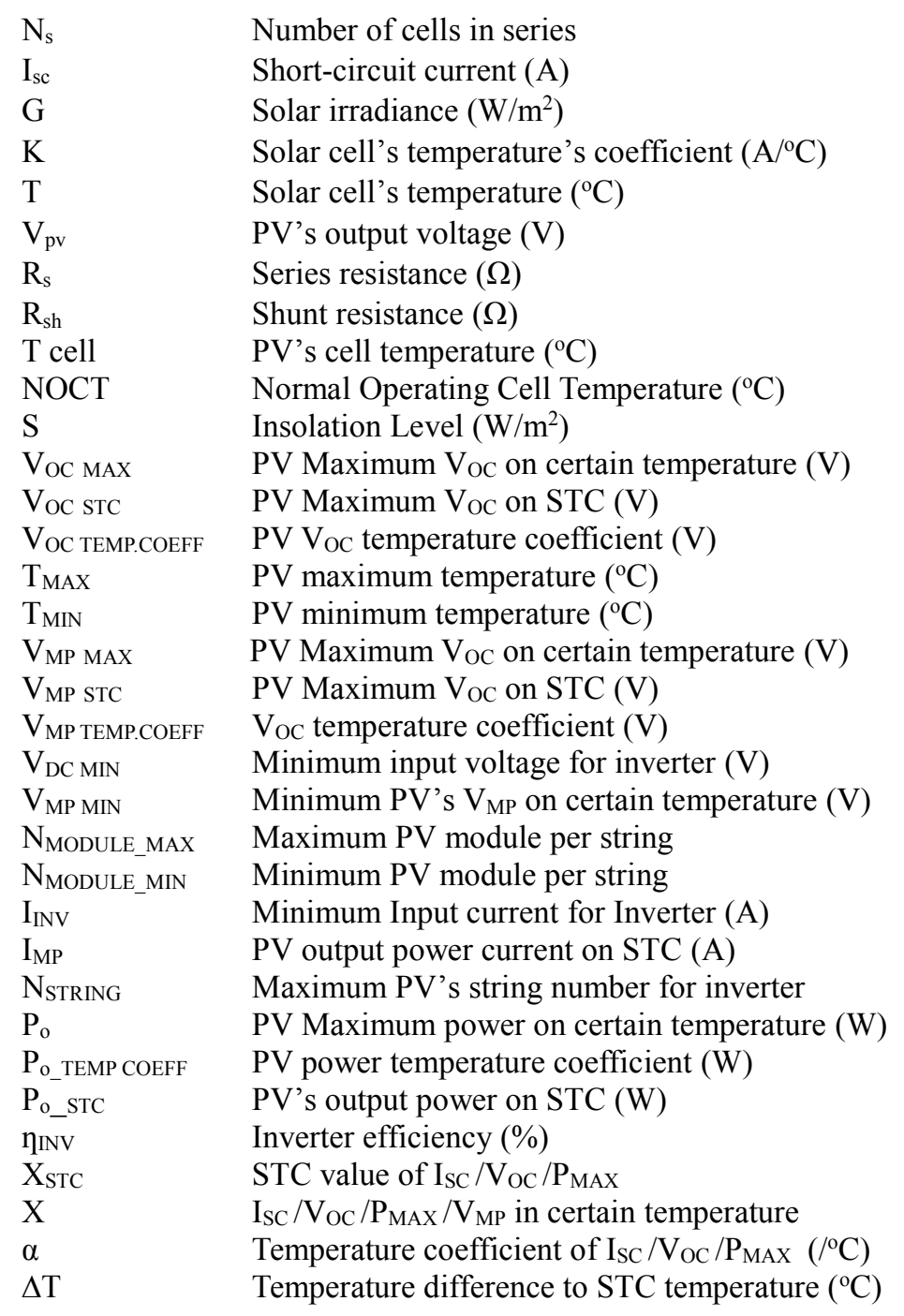

\section{REFERENCES}

[1]Solar Metric (2010) Guide to Interpreting I-V Curve Measurements of PV Arrays. Available on http://www.solmetric.com/

[2]Bowden, Stuart, Honsberg, Christiana. (2013). Instructions on Photovoltaic. http://www.pveducation.org/

[3]A. Green, M. (1998). Solar Cells Operating Principles, Technology and System Applications. Kensington: The University of New South Wales.

[4]Meteoblue (2015). General Climate Zone. Available on https://content.meteoblue.com/en/meteoscool/generalclimate-zones/tropical-zone

[5]Cramer, G.; Ibrahim, M.; Kleinkauf, W.: PV System Technologies - State of the Art and Trends in Decentralised Electrification. reFOCUS, January/February 2004.

[6]Shivananda Pukhrem (2013). A PHOTOVOLTAIC PANEL MODEL IN MATLAB/SIMULINK. Available on http://www.researchgate.net/publication/255721161

[7]Bowden, Stuart, Honsberg, Christiana. (2013). Nominal Operating Cell Temperature. http://www.pveducation.org/.

[8]N.H. Zaini, M. Z. Ab Kadir, M. Izadi, N.I. Ahmad, M.A.M Radzi and N. Azis. (2015). The Effect of Temperature on a Mono-crystalline Solar PV Panel. IEEE Conference on Energy Conversion (CENCON). Pages: 249 - 253, DOI: $10.1109 /$ CENCON.2015.7409548 